\title{
IMPACT OF L-CARNITINE SUPPLEMENTATION ON GROWTH OF BROILER CHICKEN THROUGH DETERMINATION OF CHANGES IN THE EXPRESSION OF CAT2, MYOD AND MYF5 GENES
}

\author{
Tarek K. Abouzed ${ }^{1 *}$, Doaa A. Dorghamm ${ }^{1}$, Khaled A. Kahilo ${ }^{1}$, Azza M. Elkattawy ${ }^{1}$, \\ Eldsokey Nassef ${ }^{2}$, Hanan B. El-sawy²
}

${ }^{1}$ Department of Biochemistry, Faculty of Veterinary Medicine, Kafrelsheikh University, 33516, Egypt, ${ }^{2}$ Nutrition and Clinical Nutrition Department, Faculty of Veterinary Medicine, Kafrelsheikh University, Egypt

*Corresponding author, E-mail: dosouk2000@yahoo.com

\begin{abstract}
This study explored the impact of supplementation of $\mathrm{L}$ - carnitine on the performance of broiler chicken, biochemical parameters and expression of cationic amino acid transporter (CAT2), myogenic determining factor (MYOD) and myogenic factor 5 (MYF5) genes. This study included two groups; the first one is the control group and the second one received L-carnitine at a dose $50 \mathrm{mg} / \mathrm{kg} /$ day in drinking water. After 35 day, the sera and muscle tissue were obtained for biochemical and real time polymerase chain reaction (qPCR) analysis. The obtained results revealed a significant increase in the body weight, total body weight gain and a significant decrease in food consumption, food conversion rate in L-carnitine-supplemented group as compared to the control group. Moreover, there was no significant changes in serum cholesterol, triacylglycerol, AST, ALT, total protein and uric acid levels which showed a slight decrease in Lcarnitine-supplemented group in comparison with the control group. This study also revealed a significant up regulation for the expression of CAT2, MYOD and MYF5 genes in muscles of broiler chicken-supplemented with $\mathrm{L}$ - carnitine as compared to the control one. The present study concluded that supplementation of L- carnitine to broiler chicken was useful to increase the total body weight gain and muscle mass and this beneficial effect was associated with up regulation of CAT2, MYOD, and MYF5 genes.
\end{abstract}

Key words: L-carnitine; broiler chicken; growth traits; CAT2; MYOD; MYF5

\section{Introduction}

Poultry industry has assumed an imperative role in meeting the deficiency of animal protein in world. The poultry production, particularly broiler production, is the quickest way to increase the accessibility of high quality protein for human utilization $(1,2)$.The poultry production differs from animal production in a different ways. Broiler chicken production requires between fifty to sixty days, while the formation of red meats requires 9 to 12 months. Additionally, chicken require around $3 \mathrm{~kg}$ of food (ration) to create $1 \mathrm{~kg}$ of meat, while animals should consume $7 \mathrm{~kg}$ of food to produce $1 \mathrm{~kg}$ of red meat (3).

The problem in the poultry production is containing excess body fat. There are many 
factors, for example diets and hereditary factors that increase the tendency to aggregate excess body fat. In this manner, improvement of poultry composition by other additives is consider a primary focal point of nutritional research (4).

Poultry food is fundamentally composed of soybean, maize and plant products which all have less carnitine content (5). The latter can be biosynthesized endogenously from methionine and lysine amino acids in the presence of folic acid and vitamin B3, B6, B12, and C, in addition to iron $(6,7)$. When diets are not provided with these two amino acids, the bird unable to form a sufficient amounts of carnitine (5).

Dietary L-carnitine addition induces the $\beta$ oxidation of unsaturated fats to produce adenosine triphosphate (ATP) energy and enhance energy utilization (8-10). L-carnitine has two main functions. The first is to encourage the transfer of long-chain fatty acids across the inner mitochondrial membrane, and the second is to encourage the expulsion of short and medium-chain fatty acids from the mitochondria that aggregate as a result of typical and unusual metabolism $(11,12)$. It also has an impact on fat metabolism and reduction of protein formation to form energy in chick's body ,subsequently a greater amount of energy will be oxidized and won't be decomposed in abdominal tissues (13).

Myogenic determining factor (MYOD) and myogenic factor 5 (MYF5) are a group of proteins belong to myogenic regulatory factors (MRFs). These basic helix-loop-helix (bHLH) transcription factors act consecutively in myogenic differentiation. MYOD is a key transcriptional factor for muscle differentiation and growth. MYF5 is the first myogenic regulatory protein expressed in the skeletal muscle lineage. In mammals, both MYOD and MYF5 are required for the formation of skeletal muscle (14). In chickens, MYOD and MYF5 are associated with post-hatch chicken myogenesis (15). CATs are primary amino acid transport system used by tissues to concentrate lysine, arginine and ornithine into cellular amino acid pools to be used in nitrogen metabolism (16).
This study was conducted to explore the potential effect of L- carnitine on the performance of broiler chicken, biochemical parameters and CAT2, MYOD, MYF5 genes expression.

\section{Materials and methods}

This study was conducted in the chicken experimental house at Faculty of Veterinary Medicine, Kafrelsheikh University, Egypt. A total number of 120 mixed sex Ross 308 broiler chicks at 1 day old age were obtained from a private poultry company at El-Gharbia Governorate, Egypt. All the chicks were immunized against both New Castle's disease on $7^{\text {th }}$ and $18^{\text {th }}$ days and Gumboro disease on $14^{\text {th }}$ day. The experimental birds were offered feed and water ad libitum for 5 weeks.

\section{Bird feeding}

A starter diet was available for the first 21 days then changed to a grower diet till the end of the experiment (35 days). Diets were formulated to meet the supplement recommendations for broilers by the National Research Council (17) with some modification according to updated nutrients specification of broiler chickens (Tables 1\&2).

\section{Experimental design and treatment}

One hundred and twenty chicks were allocated into two groups (60 chicks per group). Each group was subdivided into 6 replicates (10 chicks/replicate).The first group: received drinking water only and basal diet (without any additive) and was considered as the control group; and the second group received Lcarnitine (sigma Aldrich company in drinking water at dose of $50 \mathrm{mg} / \mathrm{kg} /$ day (18).

\section{Blood and tissue samples}

At the end of experiment, chickens were subjected to 12 hours feed withdrawal and then blood samples were collected from the wing veins in clean and dry Eppendorf tubes. After coagulation and centrifugation at 3000 rpm for 15 minutes clear serum samples were collected. Sera immediately kept frozen at $20^{\circ} \mathrm{C}$ until biochemical analysis. Birds were slaughtered after mild anesthesia and dissec- 
tion of skin under complete aseptic condition. Then muscle specimen was excised from breast muscle and quickly dunked in liquid nitrogen, then frozen at $-80^{\circ} \mathrm{C}$ for RNA extraction.

\section{Performance parameters}

Body weight was recorded at the end of every week. Body weight gain was calculated weekly following this equation: body weight gain = final weight - start weight. Feed intake was recorded daily according to the following equation: Feed intake=feed allowed - feed refusal. Feed conversion ratio (FCR) was calculated according to the following equation: $\mathrm{FCR}=$ feed intake/body weight gain.

\section{Biochemical analysis}

Colorimetric estimation of glucose, cholesterol, triacyl glycerol, and uric acid was done as previously described (19). Serum total protein was evaluated by colorimetric procedure based on (20). Serum enzyme activities of alanine aminotransferase (ALT) and aspartate aminotransferase (AST) were spectrophotometrically measured as previously described (21).

Quantitative determination of CAT2, $M Y$ $O D$ and MYF5 using real-time polymerase chain reaction ( $q P C R$ )

Breast muscle tissue was used to isolate total RNA using TRIZOL (GeneZOl, Lot $\neq: 30117 \mathrm{~B} 07003$, Genetix Biotech) following the manufacturer's protocol. The concentration of RNA was measured using a Nanodrop. cDNA was synthetized using HiSenScript $^{\mathrm{TM}}$ cDNA synthesis kit (Intron Biotechnology, cat.no.25014,). This was done by mixing $10 \mu \mathrm{l} 2 \mathrm{X}$ RT reaction buffer, $1 \mu 1$ enzyme mix solution, $1 \mu \mathrm{g}$ of RNA and completed with RNas free water to $20 \mu$ total volume. The mixture was incubated at $50{ }^{\circ} \mathrm{C}$ for $30 \mathrm{~min}$ and $85^{\circ} \mathrm{C}$ for $10 \mathrm{~min}$. All PCR reactions were done by utilizing SYBR Green qPCR Master Mix (Enzynomics, cat. No. RT500) and specific primers (Table 3), at the following conditions: initial denaturation at 92 ${ }^{\circ} \mathrm{C}$ for $10 \mathrm{~min}$, followed by 40 cycles of $15 \mathrm{~s}$ at
$92{ }^{\circ} \mathrm{C}, 30 \mathrm{~s}$ at $60{ }^{\circ} \mathrm{C}$ and $30 \mathrm{~s}$ at $72{ }^{\circ} \mathrm{C}$. The differences in gene expression among the different groups were estimated by using the $2^{-}$ $\triangle \triangle \mathrm{Ct}$ method (22), standardized to GAPDH and expressed as relative mRNA levels relative to the control. Melting curve analysis was performed to verify the correct product.

\section{Statistical analysis}

All data were presented as mean \pm standard error (SE). Statistical analysis was conveyed utilizing the T-independent test (Levene's test for equality of variances) to compare the significance among the groups. A value of $\mathrm{P}<0$. 05 were considered to be significant.

\section{Results}

\section{Effect of L-carnitine on performance pa- rameters}

Supplementation of L-carnitine group showed a significant increase in the final body weight as compared with control group .There were a significant increase in the body weight gain in the group received L-carnitine compared with control group. Feed intake in the control group was higher than the group treated with L-carnitine. However, feed conversion ratio was significantly lower in L-carnitine supplementation than group without supplementation (Table 4).

\section{Effect of L-carnitine supplementation on biochemical parameters}

As shown in (Table 5) the level of blood glucose, serum cholesterol, total proteins insignificantly change in chicken treated with Lcarnitine relative to the control chicken. However, the levels of the remaining serum parameters (triacylglycerol, uric acid, ALT, and AST) showed an insignificant decrease as compared to the control group.

Effect of L- carnitine on CAT2, MYOD and MYF5 expression

As shown in figure 1, the L-carnitine supplementation significantly upregulated $(\mathrm{P}<0.05)$ the expression of $C A T 2, M Y O D$ and $M Y F 5$ in comparison with the control group. 
Table 1: Ingredients composition of the diets (\%)

\begin{tabular}{|c|c|c|}
\hline Ingredients $(\%)$ & Starter diet & Grower diet \\
\hline Yellow corn & 53.55 & 58.2 \\
\hline Corn Gluten meal & 6.9 & 6.0 \\
\hline Soybean meal, $44 \%$ & 33.2 & 29.3 \\
\hline Soybean Oil & 2.5 & 3 \\
\hline Di-calcium phosphate ${ }^{1}$ & 1.8 & 1.6 \\
\hline Ground Limestone $^{2}$ & 1.2 & 1.0 \\
\hline Mineral and Vitamin premix $^{3}$ & 0.3 & 0.3 \\
\hline Salt & 0.3 & 0.3 \\
\hline DL- methionine ${ }^{4}$ & 0.1 & 0.1 \\
\hline Lysine $^{5}$ & 0.1 & 0.15 \\
\hline Choline chloride & 0.05 & 0.05 \\
\hline Total & 100 & 100 \\
\hline
\end{tabular}

${ }^{1}$ Dicalcium phosphate (contains $18 \%$ Phosphorus and $21 \%$ Calcium). ${ }^{2}$ Limestone (contain $38 \%$ calcium). ${ }^{3}$ Premix provides vitamin A (12000 Iu), vitamin D (5000 Iu), vitamin E (50 mg), vitamin $\mathrm{K} 3$ (3 mg), vitamin B1 (3 mg), vitamin B2 $(8 \mathrm{mg})$, nicotinic acid $(30 \mathrm{mg})$, pantothenic acid $(15 \mathrm{mg})$, vitamin B6 (4 mg), vitamin B12 (0.016 mg), folic acid $(2 \mathrm{mg})$, biotin $(0.2 \mathrm{mg})$, manganese $(120 \mathrm{mg})$, zinc $(100 \mathrm{mg})$, iron $(40 \mathrm{mg})$, copper $(16 \mathrm{mg})$, iodine $(1.25$ $\mathrm{mg}$ ), selenium $(0.3 \mathrm{mg})$ per $1 \mathrm{~kg}$ diet. ${ }^{4}$ DL-Methionine (Produced by Evonic Co. and contains $99 \%$ methionine).$^{5}$ Lysine $=$ lysine hydrochloride (contains $70 \%$ Lysine).

Table 2: Chemical composition of the diets.

\begin{tabular}{lll}
\hline & Starter diet & Grower diet \\
\hline Moisture (\%) & 9 & 9 \\
Dry Matter (\%) & 91 & 91 \\
Crude protein (\%) & 23.01 & 21.20 \\
Crude fat (\%) & 5.02 & 5.62 \\
Crude fiber (\%) & 3.67 & 3.78 \\
Ash (\%) & 6.23 & 5.59 \\
Calcium $(\%)^{*}$ & 1.07 & 0.95 \\
Available Phosphorus (\%)* & 0.49 & 0.45 \\
Lysine (\%)* & 1.28 & 1.20 \\
Methionine (\%)* & 0.56 & 0.52 \\
Nitrogen free extract $(\%) * *$ & 53.07 & 54.81 \\
ME (Kcal/kg)* & 3043 & 3115 \\
Calorie/protein ratio $* * *$ & 132.3 & 146.9
\end{tabular}

* ME, lysine, methionine, calcium and phosphorus were calculated according to (17).** NFE= Nitrogen free extract was calculated by difference $=100-($ moisture $\%+\mathrm{CP} \%+\mathrm{EE} \%+\mathrm{CF} \%+$ ash $\%)$. $* * *$ Calorie/protein ratio $=\mathrm{ME}$ $\mathrm{Kcal} / \mathrm{CP}$

Table 3: Sequences of primers used in qPCR.

\begin{tabular}{lll}
\hline Gene & GenBank no. & Sequence \\
\hline CAT2 & BU492799 & $\begin{array}{l}\text { Forward CAACTGGAGAAAGAGGTCAGGAA } \\
\text { Reverse AATTAGGCCATGAAGCAGACAAG }\end{array}$ \\
MYOD & NM_204214 & $\begin{array}{l}\text { Forward ATCACCAAATGACCCAAAGC } \\
\text { Reverse GGGAACAGGGACTCCCTTCA }\end{array}$ \\
& & $\begin{array}{l}\text { Forward TGAGGAACGCCATCAGGT } \\
\text { Reverse GCGAGTCCGCCATCACAT }\end{array}$ \\
FAPDH & NM_001030363204305 & $\begin{array}{l}\text { Forward ACATGGCATCCAAGGAGTGAG } \\
\text { Reverse GGGGAGACAGAAGGGAACAGA }\end{array}$ \\
\hline
\end{tabular}


Table 4: Effect of L- carnitine supplementation on performance parameters

\begin{tabular}{|l|l|l|}
\hline & Control & L. carnitine \\
\hline Initial weight $(\mathrm{g})$ & $40.20 \pm 1.8$ & $40.8 \pm 1.5$ \\
\hline Final weight $(\mathrm{g})$ & $1689 \pm 3.5^{\mathrm{b}}$ & $1731 \pm 10.1^{\mathrm{a}}$ \\
\hline Body weight gain (g) & $1648 \pm 2.6^{\mathrm{b}}$ & $1690 \pm 8.3^{\mathrm{a}}$ \\
\hline Average daily gain (g) & $47.11 \pm 0.1^{\mathrm{b}}$ & $48.29 \pm 0.29^{\mathrm{a}}$ \\
\hline Cumulative feed intake/bird & $3297.9 \pm 28.6$ & $3235.9 \pm 25.2$ \\
\hline FCR & $2.0 \pm 0.01^{\mathrm{a}}$ & $1.91 \pm 0.01^{\mathrm{b}}$ \\
\hline
\end{tabular}

Mean $\pm \mathrm{SE}$ ( $\mathrm{n}=60 /$ group) ${ }^{\mathrm{a}, \mathrm{b}}$ Means in the same raw with different superscript are significantly different $(\mathrm{P}<0.05)$

Table 5: Effect of L- carnitine supplementation on serum biochemical parameters

\begin{tabular}{lll}
\hline & Control & L- Carnitine \\
\hline Glucose $(\mathrm{mg} / \mathrm{dl})$ & $158 \pm 12.14$ & $160.8 \pm 5.46$ \\
Cholesterol (mg/dl) & $530 \pm 53.5$ & $539.2 \pm 74$ \\
Triacylglycerol (mg/dl) & $48.2 \pm 3.67$ & $39.63 \pm 7.10$ \\
Uric acid (mg/dl) & $3.32 \pm 0.30$ & $3.2 \pm 0.4$ \\
Total protein(g/dl) & $4.34 \pm 1.74$ & $4.762 \pm 0.56$ \\
ALT(U/I) & $24.5 \pm 6.11$ & $16.25 \pm 4.95$ \\
AST(U/I) & $347 \pm 18.52$ & $247 \pm 15.55$ \\
\hline
\end{tabular}

Mean $\pm \mathrm{SE}$ ( $\mathrm{n}=18$ /group) ALT (alanine transaminase), AST (Aspartate transaminase)
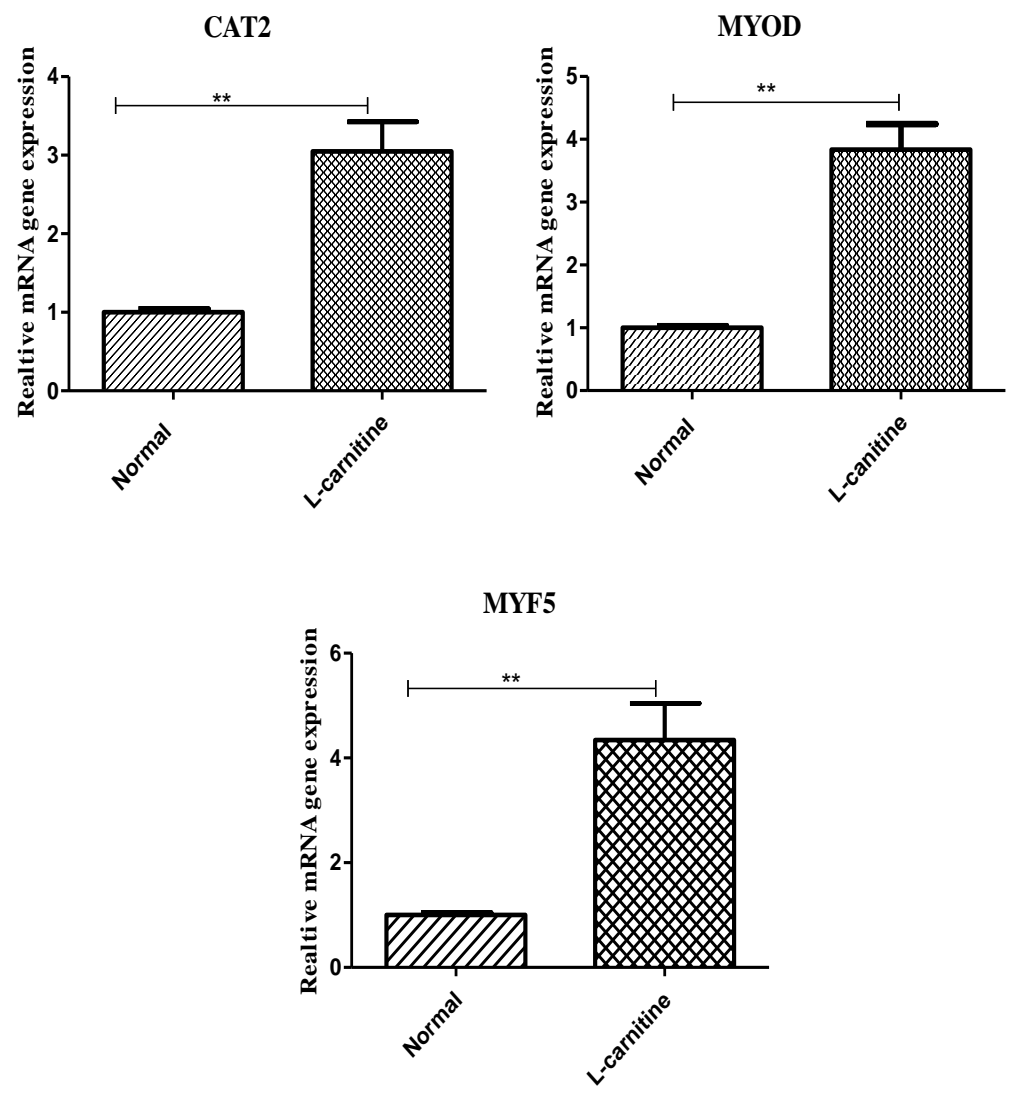

Figure 1: Quantitative real-time PCR analysis of the levels of expression of genes (A) cationic amino acid transporter (CAT 2),(B) myogenic determining factor (MYOD), (C) myogenic factor 5 ( MYF5) *P $<0.05$ versus control group ( $\mathrm{n}=18$ /group) 


\section{Discussion}

L-carnitine supplementation has a positive effect on growth rate as revealed by higher growth rate, body weight gain and lower feed consumption or feed conversion rate. These result agree with different studies which reported that, addition of L-carnitine enhance growth rates and feed potency (23). The breast or thigh meat yield were increased, and abdominal fat content was decreased by supplementation of L-carnitine (10, 23). Likewise, Lcarnitine incorporation to broiler feed enhanced body gain, improved FCR, yielded a lot of breast meat, and lowered abdominal fat depositions (13). Increased growth by addition of carnitine is also partly related to its aminoacid-sparing function in addition to its role in fat metabolism. Theoretically, the external addition of carnitine can lower the necessity for bio synthesis of carnitine from essential amino acid so stinting essential amino acid for different biological functions (24). L- carnitine can be used as a potential protecting agent against stress induced by high environmental temperatures in boilers (25).

In the contrary, some studies documented no change in growth rates or feed potency in L-carnitine-supplementation to broiler chickens (10, 26). Likewise, Leibetseder (27) reported that performance (BWG and FCR) and the content of abdominal fat of broilers weren't affected by dietary carnitine at a concentration of $200 \mathrm{mg} / \mathrm{kg}$ diet. These contradictory results may be attributed to variation in species, age, supplementary L-carnitine doses, dietary fat and protein intake. This clarification confirmed by $\mathrm{Xu}(10)$ who reported that L-carnitine at a dose of $25 \mathrm{mg} / \mathrm{kg}$ has no effects in daily body weight gain or feed conversion of birds. Whereas addition of L-carnitine at a dose higher than $25 \mathrm{mg} / \mathrm{kg}$ considerably exaggerated breast muscle yield and crude fat content of the muscles and lowered abdominal fat content.

The obtained results showed that supplementation of L-carnitine have no vital modification in blood glucose level. This is consistent with other publications which docu- mented that orally administration of Lcarnitine supplementation for 4 weeks did not effect of insulin sensitivity (28) or secretion (29).

This study revealed no significant change of cholesterol by L-carnitine supplementation and non-significant decrease Triacylglycerol, this result not consistent with Maccari (30) who documented that the significant lowered plasma triacylglycerol, cholesterol, phospholipids, nonesterified fatty acid and very low density lipoprotein concentrations (VLDL) by supplementation of L-carnitine to rats. Likewise, Amin (31) reported that adding of external L-carnitine made significant lower of serum TG, T-cholesterol. Additionally, Lcarnitine makes vital reductions in total serum cholesterol in skeletal muscles of weighty rats (32). These contradictory results may due to variation in species, age, supplementary Lcarnitine doses, dietary fat and protein intake.

Carnitine metabolism occurs mainly in the liver; therefore it is not surprising that carnitine metabolism is failed in patients and experimental animals with certain types of chronic liver disease. L-carnitine will have a therapeutic effect on certain type of liver diseases (33). Our study revealed insignificant decrease of AST, ALT, total protein. Amin (31) reported that administration of Lcarnitine make a significant lowering influence in AST and ALT activity in obese rats. Malaguarnera (34) also reported that oral Lcarnitine supplementation improve liver functions and histological findings in patients with nonalcoholic steatohepatitis. The present study revealed insignificant change in uric acid, this finding agrees with Rajasekar (35) who reported L-carnitine has beneficial effects on renal function.

The present study revealed upregulated expression of MYOD, MYF5 by L- carnitine, and this agrees with Bailey (36) who reported that $M Y O D, M Y F 5$ and variety of MRFs initiate and maintain the expression of muscle-specific genes throughout embryogenesis and postnatal muscle growth. In rats, the loss of MRFs cause reduction in body size (37). This finding confirms that the expression of $M Y O D$, 
$M Y F$ is important for increase body weight. $C A T$ s are the basic amino acid transport system utilized by tissues to concentrate lysine, arginine and ornithine into cellular amino acid pools for use in nitrogen metabolism (16), is harmonious with our finding that revealed upregulation of CAT2 expression and this associated with increased body weight and growth.

\section{Conclusion}

The present study concluded that the supplementation of L-carnitine has appositive influence on growth performance through upregulation of CAT2, MYOD and MYF5 genes.

\section{Conflict of interest}

The authors declare that they have no conflict of interest.

\section{References}

1. Qureshi A. Selecting the best feeding and watering equipment, Misset World Poultry 1991; 7: 17-9.

2. El-Magd M A, Saleh A A, Abdel-Hamid T M, Saleh R M, Afifi M A. Is really endogenous ghrelin a hunger signal in chickens?: Association of GHSR SNPs with increase appetite, growth traits, expression and serum level of GHRL, and $\mathrm{GH}$, General and Comparative Endocrinology 2016; 237(C): 131-9.

3. El Nagar A, Ibrahim A, Case study of the Egyptian poultry sector, Proceedings of the International Poultry Conference, 2007.

4. Khoshkhoo P H, Azad G A, Ila N, Moayer F, Nayeri H D, Effect of dietary L-carnitine supplementation on overall performance, carcass traits, serum components and immune response in broiler chicken, Verona, Italy: In: EPC European Poultry Conference, 2006, p. 167.

5. Arslan C. L-carnitine and its use as a feed additive in poultry feeding a review, Revue de médecine vétérinaire 2006; 157(3): 134.

6. Michalczuk M, Łukasiewicz M, Niemiec J, Wnuk A, Mroczek-Sosnowska N. Effect of Lcarnitine on performance and dressing percentage of broiler chickens, Annals of Warsaw University of Life Sciences 2012; 51: 89-99.

7. Adabi S G, Cooper R, Ceylan N, Corduk M. L-carnitine and its functional effects in poultry nutrition., World's poultry science journal 2011; 67(2): 277-96.
8. Neuman S, Lin T, Heste P. The effect of dietary carnitine on semen traits of white Leghorn roosters, Poultry Science 2002; 81(4): 495-503.

9. Corduk M, Ceylan N, Ildiz F. Effects of dietary energy density and L-carnitine supplementation on growth performance, carcass traits and blood parameters of broiler chickens, South African Journal of Animal Science 2007; 37(2): 65-73.

10. Xu Z, Wang M, Mao H, Zhan X, Hu C. Effects of L-carnitine on growth performance, carcass composition, and metabolism of lipids in male broilers, Poultry Science 2003; 82(3): 40813.

11. Matalliotakis I, Koumantaki Y, Evageliou A, Matalliotakis G, Goumenou A, Koumantakis E. L-carnitine levels in the seminal plasma of fertile and infertile men: correlation with sperm quality, International journal of fertility and women's medicine 2000; 45(3): 236-40.

12. Buyse J, Janssens G, Decuypere E. The effects of dietary L-carnitine supplementation on the performance, organ weights and circulating hormone and metabolite concentrations of broiler chickens reared under a normal or low temperature schedule, British Poultry Science 2001; 42(2): 230-41.

13. Rodehutscord M, Abel H, Friedt W, Wenk C, Flachowsky G, Ahlgrimm H-J, Johnke B, Kühl $\mathrm{R}$, Breves G. Consequences of the ban of byproducts from terrestrial animals in livestock feeding in Germany and the European Union: alternatives, nutrient and energy cycles, plant production, and economic aspects, Archives of Animal Nutrition 2002; 56(2): 67-91.

14. Rudnicki M A, Schnegelsberg P N, Stead R $\mathrm{H}$, Braun T, Arnold H-H, Jaenisch R. MyoD or Myf-5 is required for the formation of skeletal muscle, Cell 1993; 75(7): 1351-9.

15. Day K, Paterson B, Yablonka-Reuveni Z. A distinct profile of myogenic regulatory factor detection within Pax7+ cells at $S$ phase supports a unique role of Myf5 during posthatch chicken myogenesis, Dev Dyn 2009; 238(4): 1001-9.

16. Bröer S. Adaptation of plasma membrane amino acid transport mechanisms to physiological demands, Pflügers Archiv 2002; 444(4): 457-466.

17. NRC., Nutrient requirements of poultry, National Research Council. National Academy Press Washington^ ${ }^{\wedge}$ eUSA USA, 1994.

18. Grandjean D, Valette J, Jouglin M, Gabillard C, Bacque H, Bene M, Guillaud J. Dietary supplementation with L carnitine, vitamin $\mathrm{C}$ and vitamin B12 in sport dogs. Experimental 
study with sledge dogs [cyanocobalamine], Recueil de Medecine Veterinaire (France) 1993.

19. Tietz N W, Clinical guide to laboratory tests, WB Saunders Co1995.

20. Gornall A G, Bardawill C J, David M M. Determination of serum proteins by means of the biuret reaction, Journal of biological chemistry 1949; 177(2): 751-66.

21. Elkeiy M, Khamis A, El-Gamal M, Abo Gazia M, Zalat Z, El-Magd M. Chitosan nanoparticles from Artemia salina inhibit progression of hepatocellular carcinoma in vitro and in vivo, Environ Sci Pollut Res Int. doi: 10.1007/s11356-018-3339-6 2018.

22. Yuan J S, Reed A, Chen F, Stewart C N. Statistical analysis of real-time PCR data, BMC bioinformatics 2006; 7(1): 85 .

23. Rabie M H, Szilágyi M. Effects of Lcarnitine supplementation of diets differing in energy levels on performance, abdominal fat content, and yield and composition of edible meat of broilers, British Journal of Nutrition 1998; 80(4): 391-400.

24. LaCount D, Drackley J, Weigel D. Responses of Dairy Cows During Early Lactation to Ruminal or Abomasal Administration of LCarnitine1, Journal of Dairy Science 1995; 78(8): 1824-36.

25. Celik L, Öztürkcan O. Effects of dietary supplemental L-carnitine and ascorbic acid on performance, carcass composition and plasma Lcarnitine concentration of broiler chicks reared under different temperature, Archives of Animal Nutrition 2003; 57(1): 27-38.

26. Lien T, Horng Y. The effect of supplementary dietary L-carnitine on the growth performance, serum components, carcase traits and enzyme activities in relation to fatty acid $\beta$ oxidation of broiler chickens, British Poultry Science 2001; 42(1): 92-5.

27. Leibetseder J. [Effects of L-carnitine in poultry], Arch Tierernahr 1995; 48(1-2): 97-108.

28. González-Ortiz M, Hernández-González S O, Hernández-Salazar E, Martínez-Abundis E.
Effect of oral L-carnitine administration on insulin sensitivity and lipid profile in type 2 diabetes mellitus patients, Annals of Nutrition and Metabolism 2008; 52(4): 335-8.

29. Musser R, Goodband R, Tokach M, Owen K, Nelssen J, Blum S, Dritz S, Civis C. Effects of L-carnitine fed during gestation and lactation on sow and litter performance, Journal of Animal Science 1999; 77(12): 3289-95.

30. Maccari F, Arseni A, Chiodi P, Ramacci M, Angelucci L, Hulsmann W. L-carnitine effect on plasma lipoproteins of hyperlipidemic fat-loaded rats, Lipids 1987; 22(12): 1005-8.

31. Amin K A, Nagy M A. Effect of Carnitine and herbal mixture extract on obesity induced by high fat diet in rats, Diabetology \& metabolic syndrome 2009; 1(1): 17.

32. Rajasekar P, Anuradha C V. Effect of Lcarnitine on skeletal muscle lipids and oxidative stress in rats fed high-fructose diet, Journal of Diabetes Research 2007; 2007.

33. Krähenbühl S. Carnitine metabolism in chronic liver disease, Life sciences 1996; 59(19): 1579-99.

34. Malaguarnera M, Gargante M P, Russo C, Antic T, Vacante M, Malaguarnera M, Avitabile T, Volti G L, Galvano F. L-carnitine supplementation to diet: a new tool in treatment of nonalcoholic steatohepatitis - a randomized and controlled clinical trial, The American journal of gastroenterology 2010; 105(6): 1338.

35. Rajasekar P, Viswanathan $\mathrm{P}$, Anuradha C. Renoprotective action of 1-carnitine in fructoseinduced metabolic syndrome, Diabetes, Obesity and Metabolism 2008; 10(2): 171-80.

36. Bailey P, Holowacz T, Lassar A B. The origin of skeletal muscle stem cells in the embryo and the adult, Current opinion in cell biology 2001; 13(6): 679-689.

37. Knapp J R, Davie J K, Myer A, Meadows E, Olson E N, Klein W H. Loss of myogenin in postnatal life leads to normal skeletal muscle but reduced body size, Development 2006; 133(4): 601-10. 